\title{
WEED INTERFERENCE FACTORS THAT AFFECT THE GROWTH OF AN ATLANTIC FOREST TREE SPECIES
}

\author{
FATORES DA MATOINTERFERENNCIA DETERMINANTES NO CRESCIMENTO DE \\ ESPÉCIE ARBÓREA DA MATA ATLÂNTICA
}

\author{
Thainá Alves dos SANTOS ${ }^{1}$; Alexander Silva de RESENDE ${ }^{2}$; Felipe Ferreira da SILVA ${ }^{3}$; \\ Aroldo Ferreira Lopes MACHADO ${ }^{4}$; Guilherme Montandon $\mathrm{CHAER}^{2}$ \\ 1. Doutoranda em Ciências Ambientais e Florestais pela Universidade Federal Rural do Rio de Janeiro - UFRRJ, Seropédica, RJ, Brasil. \\ thaina.232@gmail.com; 2. Pesquisador da Embrapa Agrobiologia, Seropédica, RJ, Brasil. alexander.resende@embrapa.br, \\ guilherme.chaer@embrapa.br; 3. Doutorando em Ciências Ambientais e Conservação pela Universidade Federal do Rio de Janeiro - \\ UFRJ, Macaé, RJ, Brasil. felipe.ufrrj@ hotmail.com; 4. Professor da Universidade Federal Rural do Rio de Janeiro - UFRRJ, Seropédica, \\ RJ, Brasil. amachado@ufrrj.br.
}

\begin{abstract}
The objective of this study was to assess the possible existence of allelopathy and competition for water and nutrients of the grass Urochloa brizantha (Hochst. ex A. Rich.) Stapf cv. Marandu grown together with Schinus terebinthifolius Raddi in a greenhouse. The experimental design was completely randomized in a factorial scheme with 3 factors and the following levels: (1) one individual of the forest species with and without the presence of $U$. brizantha at a density of 4 individuals per pot; (2) supply of nutrients in limiting or non-limiting dose; and (3) supply of a limiting or non-limiting amount of water. We measured the height and root collar diameter of the tree seedlings, as well as the shoot and root dry weights of both species. There was competition by the grass with the tree species. The coexistence reduced the height by $30.5 \mathrm{~cm}$, the root collar diameter by $1.58 \mathrm{~mm}$ and the shoot and root dry weights by $22.7 \mathrm{~g}$ and $9.5 \mathrm{~g}$, respectively, of $S$. terebinthifolius. The greater supply of water in the pots increased the height by $18.9 \mathrm{~cm}$ of the $S$. terebinthifolius seedlings compared to the plants grown with limited water supply. Evidence was also observed of competition for nutrients, principally at the largest nutrient addition level, where the presence of the grass caused an additional decrease in the root collar diameter and shoot dry weight of the tree species, while the shoot and root dry weights of the grass increased. The results did not allow evaluating the existence of allelopathy of $U$. brizantha on $S$. terebinthifolius.
\end{abstract}

KEYWORDS: Weeds. Reforestation. Urochloa brizantha. Schinus terebinthifolius.

\section{INTRODUCTION}

Control of fast-growing exotic grass species is one of the main management practices necessary in the initial stages of reforestation in tropical environments, since these grasses can reduce the growth of the trees and impede forest regeneration (RESENDE; LELES, 2017). The negative interference of grasses on forest species (weed interference or weed competition) is associated with the competition for essential resources (water, light, nutrients and space) and possibly the production of allelopathic compounds by the grass (SILVA et al., 2009). These interactions can cause reduced growth of the tree seedlings introduced, and even their death.

Although several studies have shown the effect of weed interference on tree species (Silva, 2012), few studies have evaluated the factors that cause this interference. Souza et al. (2003) observed the effects of interference by allelopathy of 18 weed species on the initial growth of Eucalyptus grandis seedlings. Silva et al. (2000) conducted a study to identify the effects of interference of Urochloa brizantha with the absorption of nutrients by seedlings of Eucalyptus citriodora and Eucalyptus grandis in response to different levels of soil moisture. They found that the eucalypt seedlings grown together with the grass presented lower dry weight than the seedlings cultivated without grass, at all the three moisture levels studied (20,23 and $26 \%$ ), calculated based on the water retention curve of the soil utilized. The largest decrease of the concentrations of $\mathrm{NH}_{4}{ }^{+}$and $\mathrm{K}$ in the two eucalyptus species was obtained under conditions near field capacity as opposed to water stress condition, suggesting that under optimal moisture conditions, the grass is even more efficient in absorbing these nutrients.

Most studies of allelopathy involve assessing the germination of seeds of the species of interest in a substrate containing aqueous extracts with part of the plant material of the donor species. However, those studies do not simulate the real 
situation that can occur in field conditions, where recently planted individuals and weeds compete for the same resources.

The costs associated with control of weed competition after planting a forest stand are high (RESENDE; LELES, 2017), and knowledge of the level of interference caused by the competition for resources and allelopathy on the growth of tree seedlings is of fundamental importance to find the best way to suppress or remove undesired plants (MACHADO et al., 2010).

In this study, we hypothesized that the effect of weed competition on the growth of a determined species of interest is determined by the availability of nutrients and water in the soil and the sensitivity of the species to allelopathy. Therefore, the aim of this study was to assess the determining factors that influence the growth of $S$. terebinthifolius when grown together with $U$. brizantha based on an experimental design with selective exclusion of competition for water and nutrients or the effect of allelopathy.

\section{MATERIAL AND METHODS}

The study was conducted in a greenhouse, located in the municipality of Seropédica, state of Rio de Janeiro.

Standardized seedlings of the tree species Schinus terebinthifolius Raddi (Brazilian peppertree) were used as the model plant to evaluate the factors determining weed interference caused by $U$. brizantha. The experimental design was completely randomized, in a factorial scheme with 3 factors, resulting in 8 treatments with 8 repetitions of each one. The factors consisted of presence or absence of grass, presence or absence of water limitation, and presence or absence of nutrient limitation (Table 1).

Table 1. Composition of the treatments to evaluate the factor(s) of weed interference affecting the growth of seedlings of Schinus terebinthifolius Raddi (Brazilian peppertree). The sign "+" indicates the presence of the grass and the non-limiting supply of nutrients and water, while the sign "-" indicates the absence of grass and the limiting supply of nutrients and water.

\begin{tabular}{llll}
\hline Treatment & Grass & Nutrients & Water \\
\hline T1 & + & + & + \\
T2 & + & + & - \\
T3 & + & - & + \\
T4 & + & - & - \\
T5 & - & + & + \\
T6 & - & + & - \\
T7 & - & - & + \\
T8 & - & - & - \\
\hline
\end{tabular}

The experimental units consisted of tapered circular pots with capacity of 18 liters (height 33.5 $\mathrm{cm}$, lower diameter $22.50 \mathrm{~cm}$ and upper diameter $27.4 \mathrm{~cm}$ ). Each pot was filled with $18 \mathrm{~kg}$ of soil (Haplic Planosol with sandy texture), collected at a depth of $20-40 \mathrm{~cm}$ in an area near the greenhouse.

The fertilization was calculated according to the recommendation of the "Manual de calagem e adubação do Estado do Rio de Janeiro" ["Manual of liming and fertilization of the state of Rio de Janeiro"] (PORTZ et al., 2013). However, the nitrogen dose was calculated according to the recommendation of the Brazilian Institute for Forest Research and Studies (IPEF) for native seedlings (GONÇALVES, 1995). These publications make the following recommendations: $50 \mathrm{~kg} \mathrm{ha}^{-1}$ of $\mathrm{N}, 40$ $\mathrm{kg} \mathrm{ha}^{-1}$ of $\mathrm{P}_{2} \mathrm{O}_{5}, 60 \mathrm{~kg} \mathrm{ha}^{-1}$ of $\mathrm{K}_{2} \mathrm{O}, 1,000 \mathrm{~kg} \mathrm{ha}^{-1}$ of limestone, and $50 \mathrm{~kg} / \mathrm{ha}$ of fritted trace elements (FTE). Therefore, considering the effective soil depth of $0.20 \mathrm{~m}$, i.e., $2,000 \mathrm{~m}^{3}$ per hectare, and the quantity of soil used per pot $\left(0.018 \mathrm{~m}^{3}\right)$, we calculated the recommended quantity (dose of $100 \%$ or reference dose) for $18 \mathrm{~kg}$ of soil. The pots of treatments $\mathrm{T} 3, \mathrm{~T} 4, \mathrm{~T} 7$ and $\mathrm{T} 8$ were fertilized with $25 \%$ of this recommended dose and the others (T1, T2, T5 and T6) received $200 \%$ of the recommended dose. The purpose of the $25 \%$ dose was to limit the quantity of nutrients in the pot to promote competition for nutrients between the species (grass and tree), while the purpose of the $200 \%$ dose was to limit this competition. The fertilization at planting included simple superphosphate as a source of phosphorus and sulfur, dolomitic limestone as a source of lime and magnesium, and fritted trace elements (FTE BR-12) as a source of micronutrients. The nutrients were incorporated in the soil with the help of a cement mixer. The top dressing was split into two portions, applied two and four months after planting, consisting of ammonium sulfate $\left(\left(\mathrm{NH}_{4}\right)_{2} \mathrm{SO}_{4}\right)$ and potassium chloride $(\mathrm{KCl})$ (Table 2). 
Table 2. Quantities of fertilizer used in the proportions of 25\% (T3, T4, T7 and T8) and 200\% (T1, T2, T5 and T6) in relation to the reference dose.

\begin{tabular}{llll}
\hline Fertilizer & $25 \%$ of reference dose & Reference dose $(100 \%)$ & $200 \%$ of reference dose \\
\hline Dolomitic limestone & $2.25 \mathrm{~g}$ & $9.0 \mathrm{~g}$ & $18 \mathrm{~g}$ \\
Single surperphosphate & $0.45 \mathrm{~g}$ & $1.80 \mathrm{~g}$ & $3.6 \mathrm{~g}$ \\
Ammonium sulfate & $0.56 \mathrm{~g}$ & $2.24 \mathrm{~g}$ & $4.48 \mathrm{~g}$ \\
Potassium chloride & $0.22 \mathrm{~g}$ & $0.9 \mathrm{~g}$ & $1.8 \mathrm{~g}$ \\
FTE BR-12 & $0.11 \mathrm{~g}$ & $0.44 \mathrm{~g}$ & $0.88 \mathrm{~g}$ \\
\hline
\end{tabular}

* Fritted trace elements

After the base fertilization, each pot received one $S$. terebinthifolius seedling, planted in a small hole in the center. The seedlings were produced in plastic bags measuring $14 \mathrm{~cm} \times 20 \mathrm{~cm}$ (volume of $1,248 \mathrm{~cm}^{3}$ ) and had average height of 45 $\mathrm{cm}$ at the moment of planting in the pots. Then $U$. brizantha seeds were sown in the pots of treatments $\mathrm{T} 1, \mathrm{~T} 2, \mathrm{~T} 3$ and T4. After the emergence of the plantlets, they were culled, leaving four individuals per pot.

In the first 30 days after planting, the pots were irrigated with $1 \mathrm{~L}$ of water whenever necessary. After this period, the soil moisture was monitored by periodic weighing of the pots, and the quantity of water added by irrigation was distinguished between the treatments with and without water limitation. For treatments T1, T3, T5 and $\mathrm{T} 7$, the irrigation was performed whenever the moisture content of the soil reached $60 \%$ of field capacity. In these cases, the quantity of water added was only that necessary to restore the moisture of each experimental unit to $80 \%$ of field capacity. For treatments T2, T4, T6 and T8, water was only added when the plants showed the initial signs of wilting, and the soil moisture was restored to $50 \%$ of field capacity.

The field capacity of the soil was determined by the direct gravimetric method, using as tare a pot containing $18 \mathrm{~kg}$ of moist soil previously dried in an oven until reaching constant weight. Water was added to these pots until the soil reached saturation and then, after 24 hours for the excess water to drain, they were weighed again. The difference between the weights (water retained by capillarity) was $1.5 \mathrm{~kg}$ of water /18 kg of soil and was considered the weight of water needed to reach $100 \%$ of field capacity. The quantity of water to be added to each pot during the experiment was calculated by the formulas below:

$$
\begin{aligned}
& \mathrm{QH}_{2} \mathrm{O \alpha}=(80 \% F C \times D S W)+D S W-T W_{i} \\
& Q H 2 \mathrm{O} \beta=(50 \% F C \times D S W)+D S W-T W i
\end{aligned}
$$

Where: $\mathrm{QH}_{2} \mathrm{O} \alpha=$ quantity of water to be added to the pots of the treatments without water limitation ( $\mathrm{T} 1, \mathrm{~T} 3, \mathrm{~T} 5$ and $\mathrm{T} 7$ ); $\mathrm{QH}_{2} \mathrm{O} \beta=$ quantity of water to be added to the pots of the treatments with water limitation (T2, T4, T6 and T8); FC = field capacity; DSW = dry soil weight, and TW = total weight of the pot on the i-th day. The weight gain of the pots due to growth of the plants was ignored in the calculation.

The growth of the aerial part of the tree species was determined monthly by measuring the root collar diameter and total height, using a digital pachymeter (graduated in millimeters) and a measuring stick (graduated in centimeters), respectively. The measurements were performed from the date of planting until five months of age (150 days).

At 150 days, the plants were harvested and the aerial parts and roots of both species were separated. The roots were washed with tap water over a sieve to remove soil particles. The roots of $U$. brizantha and $S$. terebinthifolius were separated based on morphological aspects observed with the naked eye. The materials were placed in labeled paper bags identified by treatment, species and plant part and placed in a forced-air oven at $70{ }^{\circ} \mathrm{C}$ until reaching constant weight. Then the shoot and root dry weights of each species were determined.

\section{Data analysis}

The data were submitted to analysis of variance (ANOVA) by the F-test, after verification of the statistical requirements of homoscedasticity and normality of the distribution.

Then inferences were made regarding specific questions related to the treatments by linear fitting of multiple regressions with indicator variables (RAMSEY; SCHAFER, 2002). For this purpose, indicator variables were generated for the presence or absence of $U$. brizantha (competition), supply of water and of nutrients (with or without limitation). This analysis allowed obtaining separately the effects of the factors "competition", "water" and "nutrient" on the growth and dry weight production of S. terebinthifolius, as well as their interactions. Table 3 shows the interpretation of the multiple linear regression coefficients to assess the effect of the factors competition (presence of $U$. brizantha), nutrient and water on the growth 
variables (height, root collar diameter and dry matter accumulation) of S. terebinthifolius.
The statistical analyses were carried out with the S-PLUS version 8 software (Insightful Corp.).

Table 3. Interpretation of the multiple linear regression coefficients in relation to the effects of the factors competition (presence of $U$. brizantha), nutrient and water on the growth variables (height, root collar diameter and dry matter accumulation) of $S$. terebinthifolius.

\begin{tabular}{|c|c|c|}
\hline Factor & $\begin{array}{l}\text { Regression } \\
\text { coefficient }\end{array}$ & Interpretation of the effect on S. terebinthifolius \\
\hline \multirow{3}{*}{$\begin{array}{l}\text { Competition } \\
\text { (C) }\end{array}$} & $\mathrm{ns}^{!}$ & Presence of $U$. brizantha did not affect growth. \\
\hline & + & Presence of $U$. brizantha increased growth. \\
\hline & - & Presence of $U$. brizantha reduced growth (competition). \\
\hline \multirow{3}{*}{$\begin{array}{l}\text { Nutrient } \\
(\mathrm{N})\end{array}$} & ns & Reduced limitation of nutrients did not affect growth. \\
\hline & + & Reduced limitation of nutrients increased growth. \\
\hline & - & Reduced limitation of nutrients reduced growth. \\
\hline \multirow{3}{*}{$\begin{array}{l}\text { Water } \\
(\mathrm{W})\end{array}$} & ns & Reduced limitation of water did not affect growth. \\
\hline & + & Reduced limitation of water increased growth. \\
\hline & - & Reduced limitation of water reduced growth. \\
\hline \multirow{5}{*}{$\mathrm{C} \times \mathrm{N}$} & ns & $\begin{array}{l}\text { Effect of the presence of } U \text {. brizantha was not altered by the reduced limitation of } \\
\text { nutrients. In the presence of competition (negative coefficient "C"), the cause was } \\
\text { not associated with competition for nutrients. }\end{array}$ \\
\hline & & Effect of the presence of $U$. brizantha was positively affected by the reduced \\
\hline & + & $\begin{array}{l}\text { limitation of nutrients. In the presence of competition (negative coefficient "C"), it } \\
\text { was allayed and the cause was associated with competition for nutrients. }\end{array}$ \\
\hline & & Effect of the presence of $U$. brizantha was negatively affected by the reduced \\
\hline & - & $\begin{array}{l}\text { limitation of nutrients. In the presence of competition (negative coefficient "C"), it } \\
\text { was intensified and the cause was associated with competition for nutrients. }\end{array}$ \\
\hline \multirow{3}{*}{$\mathrm{C} \times \mathrm{W}$} & $\mathrm{ns}$ & $\begin{array}{l}\text { Effect of the presence of } U \text {. brizantha was not altered by the reduced limitation of } \\
\text { water. In the presence of competition (negative coefficient " } C \text { "), the cause was not } \\
\text { associated with competition for water. }\end{array}$ \\
\hline & + & $\begin{array}{l}\text { Effect of the presence of } U \text {. brizantha was positively affected by the reduced } \\
\text { limitation of water. In the presence of competition (negative coefficient "C"), it } \\
\text { was allayed and the cause was associated with competition for water. }\end{array}$ \\
\hline & - & $\begin{array}{l}\text { Effect of the presence of } U \text {. brizantha was negatively affected by the reduced } \\
\text { limitation of water. In the presence of competition (negative coefficient "C"), it } \\
\text { was intensified and the cause was associated with competition for water. }\end{array}$ \\
\hline \multirow[t]{2}{*}{$\mathrm{C} \times \mathrm{N} \times \mathrm{W}$} & ns & $\begin{array}{l}\text { After accounting for the effects of reduced limitation of water and nutrients, the } \\
\text { effect of the presence of } U \text {. brizantha was not altered. In the presence of } \\
\text { competition (negative coefficient "C"), the cause was associated only with } \\
\text { competition for water and/or nutrients. There was no evidence of allelopathy. } \\
\text { After accounting for the effects of reduced limitation of water and nutrients, the } \\
\text { effect of the presence of } U \text {. brizantha was positively altered. Hence, there was } \\
\text { evidence of a positive allelopathic effect. }\end{array}$ \\
\hline & - & $\begin{array}{l}\text { After accounting for the effects of reduced limitation of water and nutrients, the } \\
\text { effect of the presence of } U \text {. brizantha was negatively altered. In the presence of } \\
\text { competition (negative coefficient "C"), the cause was associated with factors other } \\
\text { than competition for water e/or nutrients. Hence, there was evidence of a negative } \\
\text { allelopathic effect. }\end{array}$ \\
\hline
\end{tabular}

\section{RESULTS}

The growth of $S$. terebinthifolius was significantly affected by the treatments, especially starting from 2 months after planting (Figure 1). The largest height values occurred in the treatments without the presence of $U$. brizantha, particularly when the plants were supplied with greater quantities of water and nutrients. In contrast, the lowest growth rates occurred when $S$. terebinthifolius was grown together with the grass, principally with lower water supply (Figure 1). Under the condition of competition and water deficit, the tree species presented reduced height between the second and third month due to the water deficit and subsequent breakage of the plants' tips. 


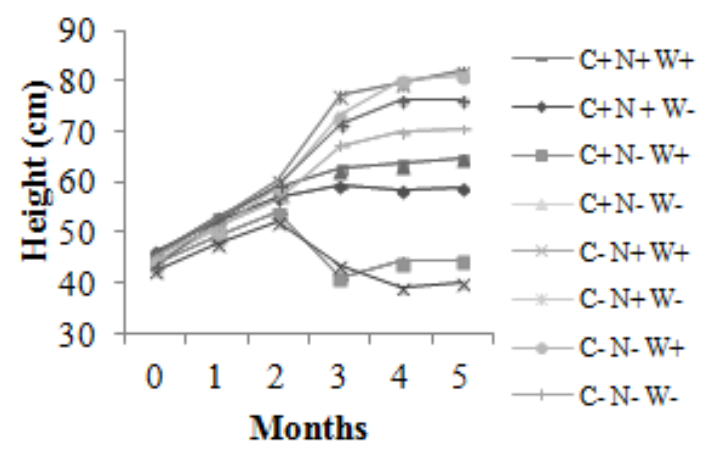

Figure 1. Growth curves of height of S. terebinthifolius seedlings during five months after planting in pots. grown in the presence ("+") or absence ("-“) of U. brizantha ("C") and/or non-limiting supply of water ("W") and nutrients ("N").

The increase of root collar diameter of $S$. terebinthifolius was influenced similar to height (Figure 2). The seedlings presented larger root collar diameters when grown without grass, especially when supplied with higher quantities of water and/or nutrients. On the other hand, the $S$. terebinthifolius plants grown with the presence of the grass presented smaller root collar diameters, particularly under the regime of low water supply and high nutrient supply (Figure 2).

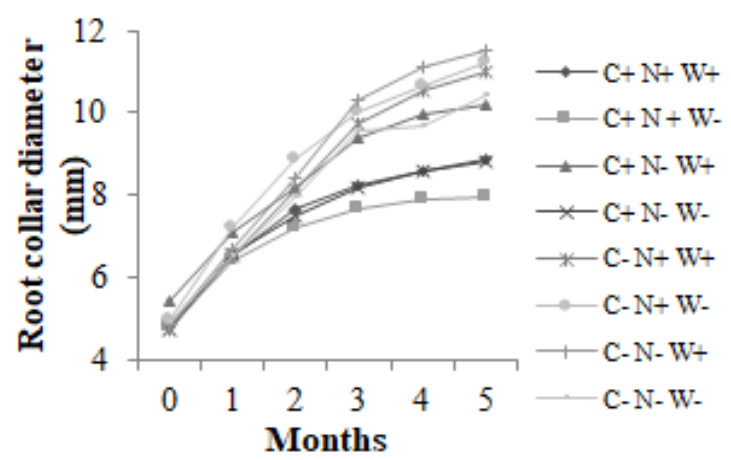

Figure 2. Growth curves of root collar diameter of S. terebinthifolius seedlings during five months after planting in pots. grown in the presence ("+") or absence ("-“) of U. brizantha ("C") and/or nonlimiting supply of water ("W") and nutrients ("N").

Table 4 reports the linear regression coefficients for the effects of the presence of $U$. brizantha and of supplementation of water and/or nutrients on the height $(\mathrm{H})$, root collar diameter (RCD), shoot dry weight (SDW) and root dry weight (RDW) of S. terebinthifolius. Based on these coefficients, it was possible to assess the individual effect of each factor studied (competition, water and nutrients) and their interactions.

The effect of competition with $U$. brizantha on S. terebinthifolius was observed in all the growth variables evaluated. In the presence of the grass, the tree plantlets' height was about $30.5 \mathrm{~cm}$ less and the root collar diameter was $1.6 \mathrm{~mm}$ smaller, while the shoot and root dry weights were $22.7 \mathrm{~g}$ and $9.5 \mathrm{~g}$ lower, respectively (Table 4).

The high supplementation of nutrients in the pots $(200 \%$ of the recommended dose) tended to promote greater growth of $S$. terebinthifolius $(0.05<$ $p<0.15$ ), with increments of approximately 10.4 $\mathrm{cm}$ in height, $0.8 \mathrm{~mm}$ in root collar diameter and $7.68 \mathrm{~g}$ in shoot dry weight (Table 4). When the high dose of nutrients was combined with the presence of $U$. brizantha ( $\mathrm{C} \times \mathrm{N}$ interaction; Table 4) there was greater competition, to the detriment of the tree species. The addition of the high nutrient dose promoted a lesser increment in root collar diameter of about $0.90 \mathrm{~mm}(-1.7 \mathrm{~mm}+0.80 \mathrm{~mm}$; Table 4) and shoot dry weight of $4.45 \mathrm{~g}(-12.13 \mathrm{~g}+7.68 \mathrm{~g}$; Table 4) in relation to the treatment with presence of the grass and low dose of nutrients. 
Table 4. Multiple linear regression coefficients for the effects of the presence of $U$. brizantha (competition, "C"), of supplementation of water ("W") and supplementation of nutrients ("N") on the height (H), root collar diameter (RCD), shoot dry weight (SDW) and root dry weight (RDW) of $S$. terebinthifolius (Brazilian peppertree).

\begin{tabular}{|c|c|c|c|c|c|c|c|c|}
\hline \multirow{3}{*}{$\begin{array}{l}\text { Parameter } \\
\text { Intercept }\end{array}$} & \multicolumn{8}{|c|}{ Coefficient } \\
\hline & \multicolumn{2}{|c|}{$\mathrm{H}(\mathrm{cm})$} & \multicolumn{2}{|c|}{$\mathrm{RCD}(\mathrm{mm})$} & \multicolumn{2}{|c|}{ SDW (g) } & \multicolumn{2}{|c|}{ RDW (g) } \\
\hline & 70.64 & $* * *$ & 10.41 & $* * *$ & 50.36 & $* * *$ & 36.94 & $* * *$ \\
\hline Competition (C) & -30.53 & $* * *$ & -1.58 & $*$ & -22.74 & $* * *$ & -9.50 & $* * *$ \\
\hline Nutrient (N) & 10.38 & $(0.09)$ & 0.80 & $(0.15)$ & 7.68 & $(0.07)$ & -2.91 & ns \\
\hline Water (W) & 5.51 & ns & 1.11 & * & 9.55 & * & 4.96 & $*$ \\
\hline $\mathrm{C} \times \mathrm{N}$ & -10.37 & $\mathrm{~ns}$ & -1.70 & $*$ & -12.13 & $*$ & -3.58 & $\mathrm{~ns}$ \\
\hline $\mathrm{C} \times \mathrm{W}$ & 18.94 & $*$ & 0.27 & ns & 7.95 & $(0.19)$ & 3.16 & ns \\
\hline $\mathrm{N} \times \mathrm{W}$ & -4.64 & ns & -1.29 & $(0.10)$ & -5.36 & ns & -2.83 & $\mathrm{~ns}$ \\
\hline $\mathrm{C} \times \mathrm{N} \times \mathrm{W}$ & -0.83 & $\mathrm{~ns}$ & 0.86 & ns & -1.97 & $\mathrm{~ns}$ & -0.67 & $\mathrm{~ns}$ \\
\hline
\end{tabular}

Under the regime of high water supplementation (moisture maintained near $80 \%$ of field capacity), the $S$. terebinthifolius plants showed increases of $1.11 \mathrm{~mm}$ in root collar diameter, $9.55 \mathrm{~g}$ in shoot dry weight and $4.96 \mathrm{~g}$ in root dry weight (Table 4). When the high water supply was combined with the presence of $U$. brizantha $(\mathrm{C} \mathrm{x} \mathrm{W}$ interaction; Table 4), the competition imposed by the grass was minimized. Under this condition, $S$. terebinthifolius grew $24.5 \mathrm{~cm}$ more in height (18.94 $\mathrm{cm}+5.51 \mathrm{~cm}$; Table 4) and gained $17.5 \mathrm{~g}$ in shoot dry weight $(7.95 \mathrm{~g}+9.55 \mathrm{~g}$; Table 4$)$, both in relation to the treatment with water restriction and grass presence.
Table 5 reports the linear regression coefficients of the effect of addition of water and/or nutrients on the shoot and root dry weight of $U$. brizantha. The high nutrient dose $(200 \%$ of the recommended one) promoted greater production of shoot dry weight and root dry weight of $U$. brizantha in relation to the low dose $(25 \%$ of the recommended dose; $p<0.001)$. Therefore, the grass plants presented $14.66 \mathrm{~g}$ more shoot dry weight and $19.71 \mathrm{~g}$ more root dry weight. There was no effect on $U$. brizantha by supplying more water in the pots.

Table 5. Multiple linear regression coefficients for the effects of supplementation of water ("W") and supplementation of nutrients ("N") on the shoot dry weight (SDW) and root dry weight (RDW) of U. brizantha.

\begin{tabular}{|c|c|c|c|c|}
\hline \multirow[b]{2}{*}{ Parameter } & \multicolumn{4}{|l|}{ Coefficient } \\
\hline & $\mathrm{SDW}(\mathrm{g})$ & & & \\
\hline Intercept & 31.84 & $* * *$ & 41.86 & *** \\
\hline Nutrient (N) & 14.66 & $* * * *$ & 19.71 & * \\
\hline Water (W) & -2.93 & ns & -6.06 & ns \\
\hline $\mathrm{N} \times \mathrm{W}$ & 4.34 & ns & 16.46 & ns \\
\hline
\end{tabular}

$p<0.001 ;{ }^{*} p<0.05 ;$ ns. not significant.

\section{DISCUSSION}

The lower growth of Schinus terebinthifolius under the condition of high water limitation can be attributed to the closing of the stomata to avoid water loss by leaf transpiration. As a consequence, the capture of $\mathrm{CO}_{2}$ is minimized, resulting in less photosynthetic activity and lower production of mass.
Furthermore, the availability of water can affect the uptake of nutrients, since a large part of the transport of nutrients in the soil is by mass flow. This process is a consequence of the difference of pressure potential, caused by the leaf surface tension due to transpiration. Therefore, water is moved from the soil solution to the plant, carrying mobile nutrients with it. With lower transpiration due to stomatal closing, the uptake of nutrients by the roots 
is also impaired, negatively influencing the production of plant biomass. However, in this study we did not observe an interaction between the factors water and nutrients $(\mathrm{N} \mathrm{x} \mathrm{W} \mathrm{interaction} \mathrm{not}$ significant; Table 3).

The large reduction of growth of $S$. terebinthifolius in combination with Urochloa brizantha clearly revealed how harmful the competition imposed by this grass is in the first months after planting the tree species. Various researchers have reported evidence that the presence of plants of the Urochloa genus can negatively influence growth of recently planted tree species (SILVA et al., 2000; TOLEDO et al., 2001; MONQUERO et al., 2011; MACIEL et al., 2011; FERREIRA et al., 2016). In the study conducted by Toledo et al. (2000), clones of Eucalyptus grandis X Eucalyptus urophylla in initial development in the presence of Urochloa decumbens, after about 1 year, presented reduction of $70 \%$ in the stem diameter and $68 \%$ in height in relation to eucalyptus plants without competition. Reduced growth of a clone of E. grandis x E. urophylla in the presence of $U$. brizantha and $U$. decumbens also was reported by Ferreira et al. (2016). The coexistence of the species caused a reduction of approximately $40 \%$ in the root collar diameter, $60 \%$ in the total dry weight and $76 \%$ in the leaf area 107 days after transplanting the seedlings.

The addition of nutrients in the pots increased the production of mass of the grass and reduced it of $S$. terebinthifolius. The data indicate that the increased availability of nutrients only favored the grass, suggesting that it has greater competitive capacity in absorbing nutrients, resulting in higher production of mass. Previous studies have shown that fertilization can alter the behavior of weeds, which can grow more intensely, becoming more competitive with the native plant of interest for reforestation (ABRAHAM et al., 2009; SHARMA et al., 2010).

The results of this study corroborate those of Pereira et al. (2012), who investigated possible effects of the interaction between top dressing and management of weeds in a stand of Eucalyptus grandis $\mathrm{x}$ E. urophylla. A higher dose of nutrients in the top dressing promoted greater leaf and stem dry weight of the eucalypts only in the absence of the weeds. When the trees coexisted with grasses, fertilization favored the latter.

In light of the mentioned studies, it is evidently important to choose the correct base fertilization and top dressing, but without neglecting control of grasses by crowing or banding by mechanical or chemical methods.
The tree species presented greater height gain when the competition for water with $U$. brizantha was reduced by supplying more water to the substrate. This fact shows that at least part of the competition imposed by the grass was due to competition for water. In contrast, Silva et al. (2004) observed that two eucalyptus species suffered greater reductions of height, root collar diameter and dry weight than grass plants, regardless of the amounts of water applied (1-water stress, 2moderate watering and 3- near field capacity). However, the largest reductions of growth of the eucalypts occurred when the soil was near field capacity and grasses were present. This can be explained by the greater grass growth under this condition, which intensified its capacity to compete for resources.

However, increasing the water applied to the pots did not augment the biomass production of the grass plants. This can be explained by the greater water use efficiency and lower transpiration coefficient of the grass species studied, which is a C4 plant. Silva et al. (2004), comparing the water use efficiency between $U$. brizantha and two eucalyptus species, found that regardless of the moisture content in the soil, the grass was more efficient in using water than the trees, i.e., it obtained a lower transpiration coefficient.

Our objective was to investigate competitive factors (water and nutrients) and allelopathy, to detect the main aspects that influence the competition and/or allelopathy faced by the species $S$. terebinthifolius when grown together with $U$. brizantha. In the case of allelopathy, we evaluated it indirectly, by observing the significance of the coefficients of the triple interaction among competition, water and nutrients. We believe these coefficients express the effect of the competitor (grass) on the reforestation species (tree) after considering the reduction (or elimination) of competition for water and nutrients. However, the prerequisite to test the truth of this premise was not achieved, i.e., it was not possible to simultaneously eliminate the effect of competition for water and for nutrients in the soil on the growth of the two species. More specifically, the results demonstrate that the higher fertilization level used was not sufficient to avoid or minimize the competition for nutrients, preventing us from assessing the existence of allelopathy of $U$. brizantha on S. terebinthifolius. Information reported in the literature (SOUZA FILHO et al., 2002; RODRIGUES et al., 2012) indicate that $U$. brizantha has potential for allelopathic activity, possibly influencing the germination of seeds and the growth of various plant 
species. In those studies, the allelopathic potential of the species varied according to the receptor species, due to the degree of sensitivity to phytochemicals. The experiments were conducted using aqueous extracts as part of the plant material of the competitor species, a method that does not reflect the real situation that can occur under field conditions, where factors can be present that are hard to control, such as the effect of plant extracts on the microbial community and on the mobilization of nutrients in the soil.

The method proposed here appears to be more suitable to study the allelopathic effect between coexisting plants, provided the plants being tested are supplied with doses of water and nutrients that significantly reduce the competition for these resources. A suggestion to improve the method is to plot nutrient response curves of the target species before the competition test, aiming to ascertain the critical nutrient doses, above which competition would cease. On the other hand, the moisture levels used in this study (maintained between 60 and $80 \%$ of field capacity), intended to preclude competition, appear to have been adequate.

The tree species investigated, $S$. terebinthifolius, has wide geographic distribution due to its extreme ecological plasticity. For this reason, it grows along most of Brazil's coastline, as well as near rivers, streams and in marshy fields of secondary formations. It also grows on dunes and on dry lands and in poor and stony soils. Finally, it can survive for up to six months in conditions of moderate water deficiency in the soil (LENZI; ORTH, 2004). Therefore, probably the effect of the competition caused by $U$. brizantha is more intense in relation to other less rustic species, although further studies are necessary to confirm this supposition.

The results of this study indicate that the competition imposed by $U$. brizantha can be attenuated if the soil moisture conditions are
SANTOS, T. A. et al

adequate. The most critical phase of susceptibility of plants introduced in reforesting is the first few months after planting. Therefore, planting during rainy periods or using other mechanisms to assure adequate water supply to the plants (e.g., irrigation, hydrogel, etc.) would mean less competition between grass and tree species, if control of weed competition is not carried out systematically. This hypothesis should be tested in field studies and supported by similar greenhouse studies as this one, using other species.

Furthermore, our results demonstrate that fertilization that does not meet the demand of both species (grass and tree) will only favor the species that is most efficient in obtaining nutrients from the soil, in this case grass. Hence, fertilization below the critical level to meet the demand of both species will favor the grass, which by producing more biomass will be better able to compete with the tree species. Obviously, this scenario will occur without adequate control of weed competition, which is not uncommon in reforestation projects in Brazil.

\section{CONCLUSIONS}

The reduced growth of $S$. terebinthifolius is caused mainly by the competition for water and competition for nutrients with $U$. brizantha.

The reduction of the limitation of water in the substrate can significantly lower the level of competition imposed by the grass.

The addition of a high dose of nutrients did not reduce the interference of $U$. brizantha in the growth of $S$. terebinthifolius. On the contrary, greater soil fertility strongly favored the production of grass biomass, thus increasing the competition for nutrients.

It was not possible to evaluate the effect of allelopathy of $U$. brizantha on $S$. terebinthifolius, since we could not eliminate the competition for nutrients.

RESUMO: O objetivo deste estudo foi avaliar a magnitude da competição por água, nutrientes e alelopatia imposta pelo capim Urochloa brizantha (Hochst. ex A. Rich.) Stapf cv. Marandu em convivência com Schinus terebinthifolius Raddi, em casa de vegetação. O delineamento experimental foi inteiramente casualizado, em esquema fatorial completo, com 3 fatores e os seguintes níveis: (1) um indivíduo da espécie florestal na ausência ou presença de $U$. brizantha, plantada na densidade 4 indivíduos por vaso; (2) fornecimento de nutrientes em dose limitante ou não-limitante e (3) o fornecimento de água sob regime limitante ou não-limitante. Foram mensuradas a altura e o diâmetro do coleto das mudas, bem como a massa seca da parte aérea e radicular das espécies. Houve competição da gramínea sobre a espécie arbórea. O convívio reduziu em $30,5 \mathrm{~cm}$ a altura, em 1,58 $\mathrm{mm}$ o diâmetro do coleto e em 22,7 g e 9,5 g as massas secas da parte aérea e das raízes de $S$. terebinthifolius, respectivamente. O maior fornecimento de água nos vasos proporcionou crescimento em altura $18,9 \mathrm{~cm}$ maior nas plantas de $S$. terebinthifolius quando comparado às plantas com fornecimento limitado de 
água. Houve também evidência de competição por nutrientes, principalmente quando houve a maior adição de nutrientes, causando um decréscimo adicional no diâmetro do coleto e na massa seca da parte aérea da espécie arbórea, enquanto que a gramínea foi favorecida com aumentos nas massas secas de parte aérea e radicular. O estudo não possibilitou avaliar a existência de alelopatia de $U$. brizantha sobre S. terebinthifolius.

PALAVRAS-CHAVE: Plantas daninhas. Reflorestamento. Urochloa brizantha. Schinus terebinthifolius.

\section{REFERENCES}

ABRAHAM, J.; CORBIN, J.; D'ANTONIO, C. California native and exotic perennial grasses differ in their response to soil nitrogen, exotic annual grass density, and order of emergence. Plant Ecology. v. 201, p. 445456, 2009. http://dx.doi.org/10.1007/s11258-008-9467-1

FERREIRA, G. L.; SARAIVA, D. T.; QUEIROZ, G. P.; SILVA, D. V.; PEREIRA, G. A. M.; FERREIRA, L. R.; OLIVEIRA NETO, S. N.; MATTIELO, E. M. Eucalypt growth submitted to management of Urochloa spp. Planta Daninha, v. 34, n. 1, p. 99-107, 2016. https://dx.doi.org/10.1590/S0100-83582016340100010

GONÇALVES, G. L. M. Recomendação de adubação para Eucalyptus, Pinus e espécies típicas da Mata Atlântica. Documentos Florestais, v. 15, p. 1-23, 1995.

LENZI, M.; ORTH, A. I. Fenologia reprodutiva, morfologia e biologia floral de Schinus terebinthifolius Raddi (Anacardiaceae), em restinga da ilha de Santa Catarina, Brasil. Biotemas, v. 17, n. 2, p. 67-89, 2004.

MACHADO, A. F. L; FERREIRA, L. R.; TUFFI-SANTOS, L. D.; VIANA, R. G. Interferência de plantas daninhas na cultura do eucalipto. In. FERREIRA, L.R.; MACHADO, A. F. L.; FERREIRA, F. A.; TUFFISANTOS, L. D. (Org.). Manejo Integrado de Plantas Daninhas na cultura do Eucalipto. Viçosa: UFV, 2010. v.1. 120p.

MACIEL, C. D. G.; POLETINE, J. P; ALVES, I. M.; RAIMONDI, M. A.; RODRIGUES, M.; BUENO, R. R.; COSTA, R. S. Coroamento no controle de plantas daninhas e desenvolvimento inicial de espécies florestais nativas. Semina: Ciências Agrárias, v. 32, n. 1, p. 119-128, 2011. https://doi.org/10.5433/1679-

0359.2011v32n1p119

MONQUERO, P. A.; PENHA, A. S.; ORZARI, I.; HIRATA, A. C. S. Seletividade de herbicidas em mudas das espécies nativas - Acacia polyphylla, Enterolobium contortisiliquum (Fabaceae), Ceiba speciosa e Luehea divaricata (Malvaceae). Planta Daninha, v. 29, n. 1, p. 159-168, 2011. http://dx.doi.org/10.1590/S010083582011000100018

PEREIRA, F. C. M.; YAMAUTI, M. S.; ALVES, P. L. C. A. Interação entre manejo de plantas daninhas e adubação de cobertura no crescimento inicial de Eucalyptus grandis x E. urophylla. Revista Árvore, v. 36, n. 5, p. 941-949, 2012. http://dx.doi.org/10.1590/S0100-67622012000500016

PORTZ, A.; RESENDE, A. S.; TEIXEIRA, A. J.; ABBOUD, A. C. S.; MARTINS, C. A. C.; CARVALHO, C. A. B.; LIMA, E.; ZONTA, E.; PEREIRA, J. B. A.; BALIEIRO, F. C.; ALMEIDA, J. C. C.; SOUZA, J. F.; GUERRA, J. G. M.; MACEDO, J. R.; SOUZA, J. N.; FREIRE, L. R.; VASCONCELOS, M. A. S.; LEAL, M. A. A.; FERREIRA, M. B. C.; MANHÃES, M.; GOUVEA, R. F.; BUSQUET, R. N. B.; BHERING, S. B. Recomendações de adubos, corretivos e de manejos da matéria orgânica para as principais culturas do Estado do Rio de Janeiro. In: FREIRE, L. R.; BALIEIRO, F. C.; ZONTA, E.; ANJOS, L. H. C.; PEREIRA, M. G.; LIMA, E.; GUERRA, J. G. M.; FERREIRA, M. B. C.; LEAL, M. A. A.; CAMPOS, D. V. B.; POLIDORO, J. C. Manual de calagem e adubação do Estado do Rio de Janeiro. Seropédica: Editora Universidade Rural, 2013. p. 257-413. 
RAMSEY, F. L.; SCHAFER, D. W. The Statistical Sleuth: A Course in Methods of Data Analysis. 2. ed. Belmont: Duxbury Press, 2002. 742p.

RESENDE, A. S.; LELES, P. S. S. O problema do controle de plantas daninhas na restauração florestal. In:

RESENDE, A. S.; LELES, P. S. S. Controle de plantas daninhas em restauração florestal. Brasília: Embrapa, 2017. p. 13-27.

RODRIGUES, A. P. D. C.; LAURA, V. A.; PEREIRA, S. R.; DEISS, C. Alelopatia de duas espécies de braquiária em sementes de três espécies de estilosantes. Ciência Rural, v. 43, n. 10, p. 1758-1763, 2012. https://doi.org/10.1590/S0103-84782012001000007

SHARMA, G. P.; MUHL, S. A.; ESLER, K. J.; MILTON, S. J. Competitive interactions between the alien invasive annual grass Avena fatua and indigenous herbaceous plants in South African Renosterveld: the role of nitrogen enrichment. Biological Invasions. v. 12, p. 3371-3378, 2010. https://doi.org/10.1007/s10530-0109730-y

SILVA, A. A.; FERREIRA, F. A.; FERREIRA, L. R.; SANTOS, J. B. Métodos de controle de plantas daninhas. In: SILVA.A. A.; SILVA, J. F. (Ed.). Tópicos em manejo de plantas daninhas. Viçosa: Ed. da UFV, 2009. p. 63-81.

SILVA, P. S. S. Atuação dos aleloquímicos no organismo vegetal e formas de utilização da alelopatia na agronomia. Biotemas, v. 25, n. 3, p. 65-74, 2012. https://doi.org/10.5007/2175-7925.2012v25n3p65

SILVA, W.; SILVA, A. A.; SEDIYAMA, T.; FREITAS, R. S. Absorção de nutrientes por mudas de duas espécies de eucalipto em resposta a diferentes teores de água no solo e competição com plantas de Brachiaria brizantha. Ciência e Agrotecnologia, v. 24, n. 1, p. 147-159, 2000.

SILVA, W.; SEDIYAMA, T.; SILVA, A. A.; CARDOSO, A. A. Índice de consumo e eficiência do uso da água em eucalipto, submetido a diferentes teores de água em convivência com braquiária. Floresta, v. 34, p. 325335, 2004. http://dx.doi.org/10.5380/rf.v34i3.2419

SOUZA, L. S.; VELINI, E. D.; MAIOMONI-RODELLA, R. C. S. Efeito alelopático de plantas daninhas e concentrações de capim-braquiária (Brachiaria decumbens) no desenvolvimento inicial de eucalipto (Eucalyptus grandis). Planta Daninha, v. 21, n. 3, p. 343-354, 2003. http://dx.doi.org/10.1590/S010083582003000300001

SOUZA FILHO, A. P. S.; ALVES, S. M.; DUTRA, S. Estádio de desenvolvimento e estresse hídrico e as potencialidades alelopáticas do capim-marandu. Planta Daninha, Viçosa, v. 20, n. 1, p. 25-31, 2002. http://dx.doi.org/10.1590/S0100-83582002000100004

TOLEDO, R. E. B.; VICTÓRIA FILHO, R.; ALVES, P. L. C. A.; PITELLI, R. A.; CADINI, M. T. D. Efeitos da faixa de controle do capim-braquiária (Brachiaria decumbens) no desenvolvimento inicial de plantas de eucalipto. Planta Daninha, v. 18, n. 3, p. 383-393, 2000. http://dx.doi.org/10.1590/S010083582000000300001

TOLEDO, R. E. B.; DINARDO, W.; BEZUTTE, A. J.; ALVES, P. L. C. A.; PITELLI, R. A. Efeito da densidade de plantas de Brachiaria decumbens sobre o crescimento inicial de Eucalyptus grandis. Scientia Forestalis, n. 60, p. 109-117, 2001. 